\title{
MAATALOUS SUOMEN KANSANTULOLASKELMISSA
}

\author{
Pentti Viita \\ Tilastollinen päätoimisto, Helsinki
}

Saapunut 2.4. 1954

Talouselämän eri puolia kuvaavat erilliset tilastot eivät useinkaan sellaisinaan pysty antamaan selvää kuvaa koko kansantaloudesta ja sen eri sektoreista. Ongelma on pyritty ratkaisemaan kansantulolaskelmilla, jotka hajanaisia tilastotietoja yhdistämällä pyrkivät kokonaiskäsitteisiin ja niissä ilmeneviin syy-yhteyksiin. Kansantulolaskelmista saadaankin aineistoa moniin tarkoituksiin, joista taloudellisen aktiviteetin ja elintason muutosten kuvaaminen ovat tärkeimpiä. Seuraavassa on tarkoitus esittää niitä periaatteita, joita maatalouden kansantulo-osuuden laskennassa käytetään Suomessa, ja samalla tarkastella maatalouden asemaa suoritettujen laskelmien valossa.

Kansantulon määritelmiä on useita. Niinpä esim. Kuznets (1) pitää sitä niiden taloudellisten hyödykkeiden nettoarvona, jotka kansantalous tuottaa tiettynä ajanjaksona. Emme voi tällöin oikeastaan puhua kansantulosta vaan kansantuotteesta. Tämä on ts. rahassa arvioitujen hyödykkeiden (tavaroiden ja palvelusten) summa, minkä kansantalous tuottaa kulutusta ja sijoitustoimintaa varten esim. vuoden kuluessa. Tästä hyödykemäärästä voi osa mennä ulkomaille pääoman korkoina tai päinvastoin, jolloin vasta päästään käsitteeseen kansantulo. Toisen määritelmän mukaan kansantulo on niiden tulojen summa, joka saadaan maassa tuotantotoimintaan osallistumisesta tiettynä ajanjaksona (7). Tällaisia tuloja ovat palkat sekä organisaatio- ja pääomatulot. Tässä yhteydessä ei liene kuitenkaan syytä tarkemmin perehtyä kansantulon teoriaan, joka on kehittynyt sangen laajaksi. Varsinkin lukuisat erilaiset käsitteet aiheuttavat helposti sekaannusta kansantulolaskelmien käyttäjille. Käsitteiden moninaisuus saa selityksensä kuitenkin kahdesta luonnollisesta seikasta. Ensiksikin ratkaisevia ovat käyttötarkoitukset, joissa laskelmia tarvitaan, ja toiseksi laskentamenetelmistä ja näiden mukana käyttökelpoisesta tilastosta joudutaan eri käsitteisiin. Kun on kysymys nimenomaan jonkin elinkeinon osuudesta kansantulolaskelmissa, on parhaimmaksi laskentametodiksi osoittautunut ns. tuotantotilastollinen menetelmä (3). Tällä voidaan selvittää kunkin elinkeinon nettokansantuote-erä tuotantokustannushintaan. Näiden erien summa, nettokansantuote, eroaa nettokansantulosta ulkomaille maksettujen tai vastaavasti saatujen pääomankorkojen verran. Kansantuote-erän laskeminen kus- 
sakin elinkeinossa tapahtuu seuraavasti. Ensiksi on selvitettävä ko. elinkeinossa tuotettujen hyödykkeiden arvo siihen hintaan, minkä tuottaja saa valtiovallan maksamat tukipalkkiot mukaanluettuna, mutta välilliset verot vähennettynä. Saadusta summasta on vähennettävä taas muilta elinkeinoilta ja ulkomailta ostettujen ja tuotantoprosessissa käytettyjen hyödykkeiden arvo sekä tuotantopääoman kuluminen. Tällä tavoin on selvillä ko. elinkeinossa syntynyt hyödykkeiden arvonlisäys. joka on juuri kansantuote-erä. Laskelma selvinnee lähemmin maatalouden osalta myöhemmin esitettävästä taulukosta.

LINDBERGin (5) käyttämät menetelmät maatalouden kansantuote-erän laskemiseksi Suomessa v. 1926-1938 poikkeavat jossain määrin nykyisistä, mutta erot eivät ole suuria. Mm. tilastollisessa päätoimistossa suoritetuilla kulutustutkimuksilla on voitu tarkistaa monia eriä varsinkin tuottopuolelta ja samalla on tapahtunut kehitystä myös käytettävissä olevien tilastojen alalla. Nykyisissä laskelmissa käytetty termi "maatalous sivuelinkeinoineen» käsittää varsinaisen peltoviljelyn ja karjatalouden lisäksi puutarhat, mehiläishoidon, metsämarjojen yms. keräilyn, turkistarhat sekä hevostyön metsätaloudessa. Laskentaperiodina on edelleen kalenterivuosi, vaikka tämä ei olekaan ehkä paras ratkaisu nimenomaan maatalouden kannalta (5, p. 25-26). Maanviljelijän tuottamien ja itse kuluttamien tuotteiden hinnoittelussa on käytetty ns. maanviljelijän luovutushintoja (5, p. 24 ja 32) eli niitä hintoja, joilla tuottaja voisi myydä tuotteensa markkinoilla. Rajankäynti eri elinkeinojen välillä tuottaa vaikeuksia. Niinpä kansantulolaskelmissa on maatalouteen katsottu kuuluvan hevostyön metsätaloudessa, mutta sen sijaan kaikenlainen rakentaminen (mm. raivaus) on luettu rakennustoimintaan ja esim. kotitarvepuun hakkuu ja ajo metsätalouteen. Seuraavassa on esitetty laskelmissa käytetty tiliasetelma.

Maatalouden ja sen sivuelinkeinojen tuotantotili.

Tuotot

I. Maataloustuotteiden myynti ja viljelijäin oma käyttö

1. Myynti suoraan kuluttajille

2. Myynti teollisuudelle ja muille elinkeinoille (esim. rehut liikenteeseen ja armeijalle)

3. Myynti ulkomaille

4. Viljelijän kotitaloudessa käytetyt oman maatilan tuotteet

II. Viljelijän varastojen muutos

III. Kotieläinpääoman muutos

IV. Tukipalkkiot, jotka eivät sisälly joko viljelijän saamiin hintoihin tai alenna viljelijän maksamia kustannuksia

V. Hevostyö metsätaloudessa

\section{Kulut}

I. Siementen, lannoitteiden, rehun ja erilaisten tarvikkeiden osto

1. Teollisuudelta ja muilta elinkeinoilta

2. Ulkomailta

II. Oman rehun jauhatuspalkkiot ja erilaiset käyttömenot

III. Kaluston ja rakennusten korjaus ja kunnossapito

VI. Poistot kalustosta ja rakennuksista

V. Nettokansantuote-erä tuotantokustannushintaan

1. Maksetut palkat ja muut menot palkkatyövoimasta

2. Viljelijän maksamat korot, vuokrat ym. näihin verrattavat menot

3. Maatalouselinkeinoa harjoittavien yhtiöiden voitot ja välittömät verot

4. Maanviljelijöiden yrittäjätulot

a. Välittömät verot

b. Nettotulot 
Asetelmasta on huomattava, että siitä puuttuvat peltoviljelyksestä saadut rehut, jotka on käytetty karjataloudessa. Laskentatyön helpottamiseksi tämä ja muut sen kaltaiset erät on jätetty pois, koska ne esiintyisivät tilin molemmilla puolilla (siis tuloina ja menoina) eivätkä vaikuttaisi nettotulokseen. Asetelman kohdista monet lienevät itsestään selviä käsitteellisesti, mutta niiden nykyisiä laskentaperiaatteita lienee syytä tässä yhteydessä kosketella pääpiirteittäin. Kunkin erän selvittely jakautuu kahteen pääongelmaan. Toinen on hyödykkeiden volyymin laskeminen kalenterivuosittain ja toinen on ko. hyödykkeiden hinnoittelu. Paljouksien arvioinnille luovat maataloustiedustelut ja vuotuistilastot maatalouden alalta pohjan, jota on täydennetty useista eri lähteistä saaduilla tiedoilla. Hinnoittelussa saadaan korvaamatonta apua Pellervo-Seuran markkinatutkimuslaitokselta, mutta myös alan myyntijärjestöt ym. ovat tärkeitä tietolähteitä. Maatalouden kokonaistuottoa ja liikekustannuksia käsittelevät laskelmat, joita prof. K. U. Pihkala on suorittanut useilta vuosilta sodan aikana (6) sekä maataloushallitus ja ns. maatalouden hintatoimikunta monilta viimeisimmiltä vuosilta, ovat olleet myös lähdeaineistona.

Tuottojen puolella erä "maataloustuotteiden myynti ja viljelijän oma käyttö» on tärkein, sillä tähän ryhmään kuuluvat mm. seuraavat maataloustuotteet:

maito, kotivoi ja kotijuusto

kananmunat, liha, vuodat ja villa

vilja, peruna ja sokerijuurikas

vihannekset

kehruu- ja öljykasvit

\author{
hedelmät, marjat ja hunaja \\ kukat ja koristekasvit \\ siemenet ja rehut \\ turkikset ja kotieläinten myynti muille sekto- \\ reille
}

Maidon tuotanto on laskettu lehmäluvun ja keskilypsyn perusteella. Edellinen on saatu vuotuisista maataloustilastoista ja jälkimmäinen vuosien 1929-30 ja 1950 maataloustiedusteluista, jota on muutettu tarkastusyhdistyksiin kuuluvien karjojen keskituotannon mukaan. Vuotuisista maataloustilastoista voidaan ehkä päästä suoraankin kokonaistuotantoon vuodesta 1951 alkaen, mutta kysymys on vielä toistaiseksi ollut avoin. Saadusta tuotannosta on tämän jälkeen vähennetty rehuksi menevä maito \%:na maatalouslaskennan perusteella. Jäännöksestä on käytetty osa rehuksi vielä kuorittuna maitona. Arviointi on suoritettu siten, että meijeritilaston ja kotivoin valmistuksen perusteella on laskettu tuotetun kuoritun maidon määrä. Tästä on vähennetty meijereiden raaka-aineena käyttämä kuorittu maito sekä kulutustutkimuksilla laskettu kulutus ja lopun on katsottu menevän eläinten rehuksi. Maidon tuotanto on näin otettu nettomääräisenä. Saatua tulosta on mahdollisuus vielä verrata meijereiden vastaanottamiin määriin, joita on käytetty myös itsenäisinä tietoina ennakoinneissa. Kananmunien tuotanto on arvioitu kanojen lukumäärän ja keskituoton perusteella. Lihan ja vuotien tuotanto voidaan laskea nykyisin kahta eri tietä nautojen, hevosten ja lampaiden osalta. Ensiksikin teurastusten kpl-määriin päästään niiden tietojen pohjalta, mitkä saadaan maataloustilastosta eri ikäisistä eläimistä. Arvioimalla syntyneiden eläinten luku ja seuraamalla tämän ja muiden ikäluokkien siirtymistä lähinnä vanhempaan ikäluokkaan saadaan selville kustakin luokasta teurastettujen luku. Toisena tietolähteenä ovat tarkastettujen eläinten ja kotiteurastusten kpl-määrät. Lihantuotannon las- 
kemiseksi tarvitaan kuitenkin eri ikäisten eläinten teuraspainot, joista ei ole olemassa kunnollisia tietoja. Sianliha on arvioitu emakoiden luvun perusteella, mutta vuodesta 1950 lähtien on mahdollisuus käyttää tarkempia tietoja tarkastamoista sekä kotiteurastuksista yli 2 ha:n tiloilla. Viljan myynneistä kerää valtion viljavarasto tilastoa, joka perustuu hankintaliikkeiden ilmoituksiin. Viljelijöiden omassa ruokataloudessa käytetty vilja on laskettu vertaamalla eri kokoisilla viljelmillä tuotettuja viljamääriä näillä tiloilla asuneiden henkilöiden kulutukseen. Viimeksi mainittu on arvioitu siten, että kirjanpitotiloilla kulutetut viljat henkeä kohden on kerrottu eri kokoisilla viljelmillä asuneiden henkilöiden luvulla. Perunan käyttö teollisuudessa saadaan suoraan teollisuustilastosta, ja kulutus ruokataloudessa on arvioitu yksinomaan kulutustutkimusten perusteella. Maassa asuva väestö on jaettu mahdollisimman homogeenisiin kulutusryhmiin ja kussakin tällaisessa ryhmässä on arvioitu kulutus eri lähteiden perusteella. Sokerijuurikkaan myynti saadaan suoraan teollisuuslaitosten ostoista. Vihanneksissa, hedelmissä ja marjoissa on käytetty ensi sijassa kulutustutkimuksia, mutta samalla tuloksia on tarkistettu monilla menetelmillä. Tällaisia ovat $\mathrm{mm}$. satotiedot, markkinointi, peltoalat, siementen myynti, tiedot hedelmäpuiden ja marjapensaiden luvuista jne. Erittäin arvokkaita ovat asiantuntijoiden arviot, jotka perustuvat etupäässä erilaisiin tuotantoedellytyksiin. Ulkomaankauppatilaston perusteella voidaan selvittää myynnit ulkomaille, joskin hintoja on korjattava esim. kuljetuksen ja pakkauksen osalta luovutushintoihin pääsemiseksi. Tilastojen heikoimpiin kohtiin kuuluu maanviljelijöiden varastojen muutosten arviointi, joka on toistaiseksi tietojen puuttuessa täytynyt jättää laskelmien ulkopuolelle. Kotieläinpääoman muutos saadaan vuotuisesta maataloustilastosta ja tukipalkkiot valtion tilinpäätöksestä tai keskusvirastoilta. Hevostyön arvo metsätaloudessa on arvioitu hevosmiesten päiväpalkkojen perusteella. Pellervo-Seuran markkinatutkimuslaitokselta ja alan keskusjärjestöiltä saatuja hintatietoja on täydennetty $\mathrm{mm}$. hallintoviranomaisten ohjehinnoilla, vienti-, tukku-, vähittäis- ja eri elinkeinojen raaka-ainehinnoilla suorittamalla niihin mahdollisia korjauksia.

Kustannuspuolen selvittämisessä ovat tärkeinä tietolähteinä ulkomaankauppaja teollisuustilastot, joista saadaan volyymitiedot usein sellaisinaan. Vastaaviin hintatietoihin on taas lisättävä kaupan välityspalkkiot ja mahdolliset verot. Muutamista kustannuseristä saadaan tiedot myyntiportaassa, jolloin mahdolliset kaupan varastojen muutokset voidaan ottaa huomioon. Korjaus-, kunnossapito- ja poistokustannukset on laskettu kirjanpitotilojen perusteella samoinkuin useita pienempiäkin eriä. Ko. tiloilta saadaan nim. edellä mainitut kustannuserät muunnettua peltohehtaaria kohden. Kertomalla tämä koko maan vastaavalla pinta-alalla päästään kokonaislukuihin.

Kun tuottojen bruttomäärästä vähennetään edellä kosketellut kustannukset, päädytään nettokansantuote-erään. Kuten tämän alajaottelusta näkyy, se on korvausta tuotantotoimintaan osallistumisesta sekä palkkatyövoimalle, yrittäjille että pääomalle. Tämän nettokansantuote-erän suuruus riippuu toisaalta bruttotuloista, joihin vaikuttavat sekä tuotannon määrä että hinnat maatalouden valtiolta saama tuki mukaanluettuna, toisaalta kustannuksista. Nettokansantuote-erän jakautu- 
minen tuotantotoimintaan osallistuvien tuotannontekijöiden kesken riippuu sekin sekä volyymistä että hinnoista. Palkkamenoihin, jotka ovat tässä tapauksessa korvausta vain peltoviljelys-, puutarha- ja kotieläintaloustöistä, vaikuttavat palkkatyövoiman käyttö ja palkat. Korkomenot (laajassa merkityksessä) määräytyvät taas maanviljelijöiden velkojen määrän ja korkokannan mukaan. Jäännös, jos ei oteta huomioon vähäistä yhtiöiden osuutta, on maanviljelijän yrittäjätuloa, joka on selvyyden vuoksi vielä jaettu kahteen osaan, nimittäin julkiselle taloudelle meneviin välittömiin veroihin ja yrittäjien nettotuloihin. Tähän yrittäjätuloon sisältyy maanviljelijälle korvaus sekä hänen suorittamastaan työstä että hänen tuotantotoiminnassa käyttämästä omasta pääomasta. Kansantulolaskelmissa on pyritty selvittämään myös nettokansantuote-erän jakautuminen em. kolmeen ryhmään. Palkkakustannusten arvioinnille saatiin perusta vuoden 1950 maataloustiedustelusta työllisyyden osalta ja palkkatietoina on käytetty sosiaaliministeriön keräämiä tilastoja. Toistaiseksi on kuitenkin työllisyyden vaihteluiden selvittämiseksi täytynyt turvautua erittäin karkeisiin menetelmiin. Korot on laskettu vuosittain julkaistujen luottovolyymi- ja korkotasotietojen pohjalta. Jäännöserä on vihdoin katsottu maanviljelijöiden yrittäjätuloksi.

Tässä yhteydessä lienee syytä verrata edellä selostettuja laskelmia ns. maatalouden hintatoimikunnan maataloustulosta tekemään laskelmaan (2). On aluksi todettava, että teknillisesti molemmat selvitykset seuraavat samoja linjoja, mutta kansantulolaskelmissa maatalouteen on sisällytetty myös eriä, joita ei ole hintatoimikunnan selvityksessä. Nettokansantuote-erä on myös periaatteessa laajempi käsite kuin edellä mainittu hintatoimikunnan laskema maataloustulo. Viimeksi mainittu sisältää vain maanviljelijöiden yrittäjätulot vähennettyinä julkiselle taloudelle maksetuilla välittömillä veroilla. Jos nämä verot lisätään em. maataloustuloon, saadaan periaatteessa sama käsite kuin kansantulolaskelmien yrittäjätulo. Kun summaan yhdistetään vielä maataloudessa maksetut palkat ja korot, ollaan käsitteessä nettokansantuote tuotantokustannushintaan.

Edellä esitetty riittänee osoittamaan ne nykyiset periaatteet, joita maatalouden ja sen sivuelinkeinojen nettokansantuote-erän ja tämän alaryhmien laskennassa käytetään. Vaikka menettelyt useissa tapauksissa ovat karkeahkoja etupäässä heikosta tilastomateriaalista johtuen, voinevat laskelmat kuitenkin osoittaa kehityksen suhteellisen muutoksen, mikä on nimenomaan käytännön talouspolitiikalle tärkeintä. Sen sijaan tasokorjaukset jäävät myöhempien tutkimusten varaan, jolloin nimenomaan pitkien aikasarjojen ja eri puolilla talouselämää suoritetuilla erillistutkimuksilla päästään mahdollisimman oikeaan tulokseen. Samalla jatkuva tilastomateriaalin paraneminen tekee nykyisin suoritettavat ja tulevat laskelmat entistä tarkemmiksi. Tilastollisessa päätoimistossa onkin jo usean vuoden ajan suoritettu tätä tarkistustyötä, joka maatalouden osalta vaikuttaa lähinnä bruttotulojen volyymiin. 


\section{Laskelmien tuloksia}

Edellä olevin varauksin esitetään seuraavassa muutamia kansantulolaskelmien tähänastisia tuloksia. Vuosien 1926-1938 tiedot on saatu LindBERGin tutkimuksesta ja vuodet 1939-1948 Laurilan artikkelista (4). Nykyisin laskelmat julkaistaan vuosittain valtion tulo- ja menoarvion liitteenä olevassa taloudellisessa tilannekatsauksessa. Seuraavassa on kuitenkin aluksi julkaistu kirjoittajan laskelma maatalouden ja sen sivuelinkeinojen nettokansantuote-erästä vuosilta 1920 - 1926, jolloin saadaan kokonaiskuva maatalouden kehityksestä lähes koko itsenäisyyden ajalta. Näiden laskelmien suorittaminen on tapahtunut LindBerGin teoksessa esitettyjen periaatteiden mukaan ottaen huomioon kuitenkin ne tulokset, joita on saatu viimeisimmistä kulutustutkimuksista. Näitä on hieman kosketeltu jo edellä. LINDBERGin tutkimuksesta poiketen on meijeritoiminta luettu teollisuuteen, kun taas LINDBERGin tavoin hevostyö metsätaloudelle on jäänyt maataloustulojen ulkopuolelle. Laskelmien yksityiskohtainen selostaminen tässä veisi kuitenkin suhteettoman paljon tilaa, joten taulukossa 1 on julkaistu vain lopputulokset.

LiNDBERGin arvio v. 1926 on meijeritoiminta poisluettuna $4.00 \mathrm{mrd} \mathrm{mk}$. Tämän ja taulukossa 1 olevan luvun (3.59 mrd mk) ero johtuu etupäässä ihmisten ravinnoksi käytettyjen viljamäärien erilaisesta arvioinnista. Taulukosta nähdään sekä hintojen että tuotannon volyymin kehitys. Erikoisesti on huomattava v. 1921 maataloudelle edullinen hintakehitys ja v. 1923 kato. Ko. ajanjaksona on kuitenkin maataloustuotannon volyymi pysynyt lähes samalla tasolla ja tätä kehitystä on jatkunut LindBERGin laskelmien pohjalta tehtyjen arviointien mukaan aina v. 1929 saakka. V. 1938 hinnoissa laskettujen bruttotulojen yleinen suunta on tosin ollut v. 1920 - 1926 nouseva, mutta samanaikaisesti kohoaa väkilantojen ja ulkomaisten rehujen käyttö nopeasti. Tuntuu kuitenkin siltä, että esim. tuontirehujen käyttö v. 1926 ei ole ollut niin suurta kuin tuontitilasto osoittaa, koska v. 1927 tuonti on jo pienempää, mikä johtuu mahdollisesti runsaista varastoista v. 1926 lopussa: Varastotilastojen puuttuessa ei tätä yms. mahdollisia virheitä ole voitu korjata.

Taulukko 1. Maatalouden ja sen sivuelinkeinojen nettokansantuote-erä tuotantokustannushintaan Suomessa vuosina $1920-1926$.

Tabelle 1. Net national production at factor cost for agriculture in Finland during 1920-1926.

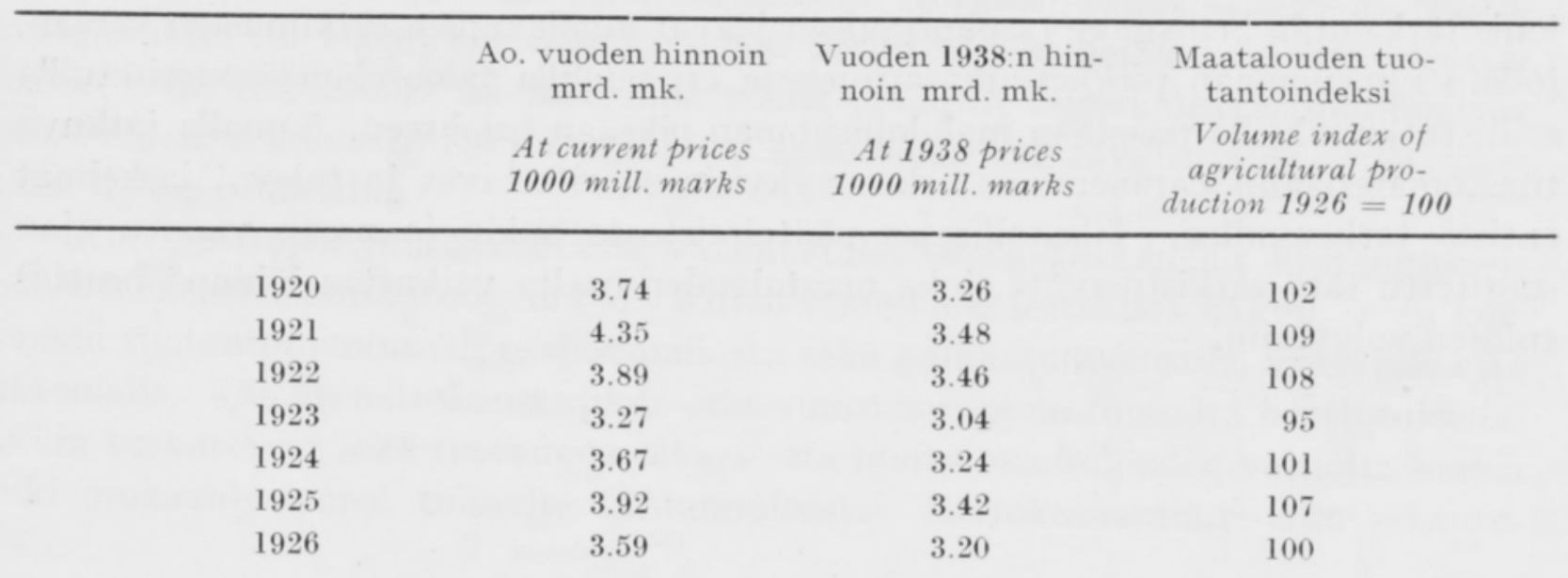


Seuraavassa ei ole ryhdytty kuitenkaan toistamaan niitä lukuja, joita on saatavana kansantulolaskelmista em. julkaisuista, vaan on tyydytty kuvaamaan maatalouden asemaa lähinnä eräillä indeksisarjoilla. Taulukosta 2 käy selville maataloustuotannon volyymi ajalta 1926-1952 sekä eräitä vertailuja. Reaalikansantuloon on luettu myös puolustuslaitos. Jos verrataan toisaalta maatalouden ja toisaalta muiden elinkeinojen tuotannon reaalista kehitystä em. vuosina, huomataan ensiksikin, että nämä kaksi sarjaa lähtevät samalta tasolta v. 1926-27. V. 1928 alkaen maatalouden tuotanto nousee aina v. 1939 saakka, kun taas muut elinkeinoalat alenevat v. 1929-1931 talouspulan vuoksi nousten jälleen v. 1936-1938 maatalouden tasolle. Sodan jälkeisinä vuosina on maatalouden volyymi noussut ripeästi, mutta muiden elinkeinojen volyymin taso on ollut kaikkina ko. vuosina huomattavasti

Taulukko 2. Maatalouden asema Suomen kansantaloudessa v. 1926-1952.

Tabelle 2. Agriculture in the national economy of Finland during 1926-1952.

\begin{tabular}{|c|c|c|c|c|c|}
\hline & $\begin{array}{l}\text { Reaalikansan- } \\
\text { tulon indeksi }\end{array}$ & $\begin{array}{l}\text { Maatalouden } \\
\text { tuotanto } \\
\text { indeksi }\end{array}$ & $\begin{array}{l}\text { Muiden elin- } \\
\text { keinojen paitsi } \\
\text { maatalouden } \\
\text { tuotantoindeksi }\end{array}$ & \multirow{2}{*}{\multicolumn{2}{|c|}{$\begin{array}{l}\text { Maatalouden nettokansantuote- } \\
\text { erä \% nettokansantuotteesta } \\
\text { tuotantokustannushintaan } \\
\text { Agricultural net national product as } \\
\text { percentage of the whole net national } \\
\text { product at factor cost }\end{array}$}} \\
\hline & $\begin{array}{l}\text { Index of the } \\
\text { real national } \\
\text { income }\end{array}$ & $\begin{array}{c}\text { Volume index } \\
\text { of agricultural } \\
\text { production }\end{array}$ & $\begin{array}{c}\text { Volume index of } \\
\text { production except } \\
\text { agriculture }\end{array}$ & & \\
\hline & $1938=100$ & production & agriculture & $\begin{array}{c}\text { Ao. vuoden } \\
\text { hinnoin } \\
\text { At current prices }\end{array}$ & $\begin{array}{l}\text { Vuoden } 1938: \mathrm{n} \\
\text { hinnoin } \\
\text { At } 1938 \text { prices }\end{array}$ \\
\hline
\end{tabular}

$\begin{array}{lr}1926 & 64 \\ 1927 & 70 \\ 1928 & 72 \\ 1929 & 72 \\ 1930 & 70 \\ 1931 & 67 \\ 1932 & 69 \\ 1933 & 73 \\ 1934 & 83 \\ 1935 & 85 \\ 1936 & 90 \\ 1937 & 99 \\ 1938 & 100 \\ 1939 & 97 \\ 1940 & 86 \\ 1941 & 91 \\ 1942 & 95 \\ 1943 & 104 \\ 1944 & 102 \\ 1945 & 87 \\ 1946 & 98 \\ 1947 & 104 \\ 1948 & 111 \\ 1949 & 116 \\ 1950 & 124 \\ 1951 & 136 \\ 1952 & 134\end{array}$

65
68
61
66
76
78
80
83
89
87
89
97
100
101
79
66
64
73
66
62
67
70
84
96
98
101
100

$\begin{array}{r}64 \\ 70 \\ 74 \\ 73 \\ 69 \\ 65 \\ 66 \\ 71 \\ 81 \\ 84 \\ 91 \\ 100 \\ 100 \\ 96 \\ 87 \\ 97 \\ 102 \\ 111 \\ 110 \\ 92 \\ 105 \\ 112 \\ 118 \\ 121 \\ 130 \\ 144 \\ 142 \\ \hline\end{array}$

22

19

0

72

72

70

67

73

$13 \quad 14$


maatalouden yläpuolella. Taulukossa 2 on laskettu myös maatalouden nettokansantuote-erän osuus \%:na koko nettokansantuotteesta sekä ko. vuosien että v. 1938 hinnoin. Näistä kahdesta sarjasta näkyy mm. kansantuote-erän hintojen kehitys verrattuna vuoteen 1938. Niinpä v. 1930-1934 hinnat ovat olleet maataloudelle epäedullisemmat kuin v. 1938. Sen sijaan 1920-luvulla, v. 1935-1937, sekä viime sodan aikana aina v. 1949 saakka hinnat ovat olleet edullisemmat kuin v. 1938. Toisena seikkana on huomattava, että maatalouden osuus nettokansantuotteesta on reaalisesti alemmalla tasolla sodan jälkeen kuin ennen sitä. Sen sijaan nimellishinnoin ko. osuus on alentunut vasta v. 1947 lähtien. Syitä, joiden vuoksi maatalouden nettokansantuote-erän kehitys on seurannut yleisen taloudellisen kehityksen mukana v. 1926-1939, mutta jäänyt viime sodan jälkeen muiden elinkeinojen tason alapuolelle, on käsitelty hyvinkin paljon. Niinpä ei voi olla toteamatta, että valtion tukitoimenpiteillä on ollut varmasti huomattava osuus 1930-luvun edulliseen tulokseen. Sen sijaan maatalouden tuotantoon jarruttavasti viime sodan jälkeen ovat vaikuttaneet mm.: laaja asutustoiminta, joka on osaltaan ehkäissyt rationalisointia, tuotantopääoman supistuminen sodan seurauksena, työvoiman virtaaminen maataloutta nopeammin kehittyviin elinkeinoihin sekä kysynnän suuntautuminen elintason nousun mukana yhä enemmän muuhun kuin animaalis-fysiologiseen kulutukseen. Jos virallisesti tilastosta saatavat puutarha- ja peltomaa sekä kotieläinten luku painotetaan yhteen tilivuoden 1938-1939 kirjanpitotiloilta saaduilla arvoilla, saadaan jonkinlainen kuva reaalisesta tuotantopääomasta, johon tosin eivät sisälly kalusto, koneet eivätkä rakennukset. Näin laskien oli em. pääoma laskenut vuodesta 1939 vuoteen 1945 n. 11.4 \% ollen v. 1950 vielä n. $6 \%$ alle v. 1939 tason. On kuitenkin otettava huomioon tuon pääoman laadun paraneminen, joka on ilmeinen esim. lehmien kohdalla kohonneesta keskituotannosta päätellen. Väestölaskentojen perusteella voidaan todeta myös maa- ja metsätalouden piiriin kuuluvan väestön sekä suhteellista että absoluuttista alenemista. Kulutuksen rakenteen muutosta ei voida toistaiseksi todeta laskelmien ollessa keskeneräisiä muuta tietä kuin kansantulon elinkeinojaoituksen perusteella.

Mielenkiintoisen ongelman muodostaa myös nettokansantuote-erän jakautuminen palkkoihin, korkoihin ja yrittäjätuloihin. V. 1938 ja 1951 muodostavat palkat yms. n. $20 \%$ maatalouden nettokansantuotteesta alustavien laskelmien mukaan. On tosin todettava alentumista palkkatyövoiman käytössä, mikä johtuu paitsi rationalisoinnista osittain myös palkkatyövoiman siirtymisestä asutustoiminnan seurauksena maatalousyrittäjiksi, mutta samalla palkkataso on noussut voimakkaammin kuin vastaava yrittäjätulo. Korkojen osuus nettokansantuote-erästä on n. $4 \%$ v. 1938 ja n. $3 \%$ v. 1951. Vastaava yrittäjätulo on taas n. 76 ja n. $77 \%$.

Edellä esitetyt laskelmat kuvaavat vain varsinaisen maatalouden ja sen sivuelinkeinojen kehitystä. Jos halutaan saada selville ns. maatalousväestön elintaso ja tulot, on huomiota kiinnitettävä myös mm. metsätalouteen ja rakennustoimintaan. 


\title{
KIRJALLISUUTTA
}

(1) Kuznets, Simon 1941. National Income and Its Composition, 1919-1938. Vol. I, p. 3. New York.

(2) Maatalouden hintatoimikunnan 31. 1. 1953 tekemä ehdotus laskelmineen ja liitteineen (moniste), Helsinki 1953.

(3) Laurila, Eino H. 1949. Maamme kansantulolaskelmat ja niiden kehittämismahdollisuudet. Kansantaloudellinen Aikakauskirja, 45.

(4) - 1950. Suomen kansantulo vuosina 1926-1949. Tilastokatsauksia 1950, 11-12, p. 48-61.

(5) Lindberg, Valter 1943. Suomen kansantulo vuosina 1926-1938. Suomen pankin suhdannetutkimusosaston julkaisuja, sarja B: 1, p. 31-56. Helsinki.

(6) Pinkala, K. U. 1945. Laskelmia maanviljelyksen taloudellisista edellytyksistä sotavuosina. Maataloustieteellinen Aikakauskirja, 17, p. 79-100.

(7) Ruggles, Richard 1949. An Introduction to National Income and Income Analysis, p. 72 - 73 New York, Toronto and London.

\section{SUMMARY:}

\author{
AGRICULTURE IN THE COMPUTATION OF THE NATIONAL INCOME IN \\ FINLAND \\ Pentit Viita \\ Central Statistical Office, Helsinki
}

The value added method has been used in the computation of the national income in Finland. The agricultural net national product consists of: receipts from sales, products for own use on the farms, change in value of stock and livestock, horse work furnished by agriculture to forestry less all purchased materials and services, repairs, maintenance and depreciation. The agricultural net national product is divided further into wages and salaries, interest and total income of farmer (= operator's income). In table 1 are given the agricultural net national product and the volume index of Finnish agriculture during 1920 - 1926. In table 2 is shown the position of agriculture in the national economy during 1926 1952. In the period 1926 - 1939 the agricultural prduction, in fact, accompanies the general economic development, but since World War II all other industries have been on a much higher level than agriculture. Wages and salaries represent about 20 per cent of the agricultural net national product in 1938 and 1951; the total income of farmer is about 76 and 77 per cent of it. 